\title{
Online Tourist Behaviour: An Evaluation of the Tourism Industry of India
}

\author{
Bivek Datta* and Sajnani $\mathrm{M}^{\dagger}$
}

\section{Abstract}

A review of literature pertaining to online travel behaviour shows that most travel purchases in India are done online. In India, $68 \%$ of the population book flight tickets directly. India has an urban adult population of 240 million out of which $27 \%$ or 65 million go on holidays. India has 205 million internet users and 110 million Smartphone users. Online Travel bookings are expected to grow rapidly as India's online travel penetration is expected to increase It is not only restricted to online product purchases. This paper is an attempt to discuss online tourist behaviour in the burgeoning Tourism Industry. The paper also looks into some key aspects such as the performance of the service sector, E-commerce and development of internet which are majorly responsible for developing customer expectation. It also throws light on online tourist behaviour and means of delivering a good experience to the tourists through an array of online services.

Keywords: Online Tourist behaviour, Tourism, Services sector, Digital travel service

\section{Introduction}

Tourism is a highly dynamic and sensitive industry which has grown exponentially in the last six decades from 25 million foreign

* Amity University, Uttar Pradesh, India; bdatta@amity.edu

† Amity University Uttar Pradesh, India; msajnani@amity.edu 
tourist arrivals in 1950 to 1235 million foreign tourist arrivals reported in 2016 (UNWTO World Tourism Highlights, 2017). The foreign exchange earnings owing to tourism have increased manifold from 2 billion USD in 1950 to 1220 billion USD in 2016 (UNWTO World Tourism Highlights, 2017).In India, tourism has been recognised as an economic activity of much value. The foreign tourist arrivals have reached 8.9 million in 2016, and as a result of these arrivals, India has earned a massive 23.5 billion USD. which has helped India to gain the $14^{\text {th }}$ position globally in terms of International Tourism Receipts in 2016 (MoT,2016).

Table 1: Foreign Tourist Arrivals s in India

\begin{tabular}{ccc}
\hline Year & FTA in Million(India) & Annual Growth(\%) \\
\hline 2000 & 2.64 & 6.7 \\
2001 & 2.53 & -4.2 \\
2002 & 2.38 & -6.0 \\
2003 & 2.72 & 14.3 \\
2004 & 3.45 & 26.8 \\
2005 & 3.91 & 13.3 \\
2006 & 4.44 & 13.5 \\
2007 & 5.08 & 14.3 \\
2008 & 5.28 & 4.0 \\
2009 & 5.16 & -2.2 \\
2010 & 5.78 & 11.8 \\
2011 & 6.3 & 9.2 \\
2012 & 6.58 & 4.3 \\
2013 & 6.96 & 5.9 \\
2014 & 7.7 & 10.2 \\
2015 & 8.03 & 4.5 \\
2016 & 8.8 & 9.7 \\
\hline
\end{tabular}

Source: Foreign Tourist Arrivals in India BOI (2016)

To manage this gigantic industry, service providers and travel aggregators are always on the move and have taken the challenging task of making available their impeccable services for prospective tourists. The service sector is a major contributor to the economic growth of the country and has presented $62 \%$ to the total gross value growth in 2016. Though the growth regressed in 201617 to $7.7 \%$ in comparison to the preceding year when it was $9.7 \%$, 
the overall scenario looks quite promising for the services sector in India.

The overall growth rate of the service sector in 2016-17 suffered a jolt in line with the global trend but few appreciable points to talk about is the growth of the aviation sector in particular.

Table 2: Performance of Services Sector: International Comparison

\begin{tabular}{lccccc}
\hline Country & $\begin{array}{c}\text { Rank in } \\
\text { Overall } \\
\text { GDP }\end{array}$ & $\begin{array}{c}\text { Rank in } \\
\text { Services }\end{array}$ & $\begin{array}{c}\text { Services } \\
\text { growth } \\
\text { rate }(\%) \\
2001\end{array}$ & $\begin{array}{c}\text { Services } \\
\text { growth } \\
\text { rate }(\%) \\
2015\end{array}$ & $\begin{array}{c}\text { CAGR (\%) } \\
2010-2015\end{array}$ \\
\hline USA & 1 & 1 & 2.0 & 2.8 & 1.6 \\
China & 2 & 6 & 10.3 & 8.3 & 8.4 \\
UK & 5 & 4 & 3.4 & 2.4 & 2.2 \\
India & 7 & 13 & 7.2 & 9.0 & 8.5 \\
Brazil & 9 & 10 & 2.2 & -2.7 & 1.3 \\
South Korea & 11 & 12 & 4.9 & 2.9 & 3.0 \\
Mexico & 15 & 9 & 1.1 & 3.6 & 3.4 \\
World & -- & --- & 2.6 & 2.6 & 2.4 \\
\hline
\end{tabular}

Source: UN National Accounts Statistics, ILO and World Bank Data Base

The aviation sector, especially domestic air travel, and tourismrelated services, especially foreign exchange earnings, have increased manifolds. The Government of India is quite positive about the growth of the tourism industry and has adapted various growth strategies to stimulate tourism. The launch of e-Tourist Visa in 2015 and its extension to 161 countries is a huge step towards this direction. The government is also promoting India as an all year destination; the launch of the Tourist Infoline and Swachh Paryatan Mobile app is noteworthy.

Source: UN National Accounts Statistics, ILO and World Bank Data Base

Globalization has transformed the services sector and has presented opportunities as well as challenges to this sector. Since services are intangible, inseparable and perishable, they need to be meticulously packaged in a bouquet so that the customers can identify their attributes easily. Tourism Industry is a crucial facet of the service sector. Tourism sector includes accommodation, transportation, entertainment and attractions and has contributed 7.6 trillion USD in 2016 to the global economy. The direct economic 
impact of accommodation, transportation, entertainment and attraction alone was 2.3 trillion USD in 2016. The needs and preferences of the tourists differ, and this presents a challenge to the service providers for providing quality services to the prospective tourists.

Tourist psychology is a very complex discipline, and service providers such as airlines, hotels, and online travel aggregators are devising innovative strategies to satisfy the existing travellers as well as striving hard to cater to the preferences and changing needs of the prospective travellers. The advent of Internet has revolutionised the Tourism Industry and has presented an opportunity to take full advantage of travel aggregators, which has increased tourist satisfaction and loyalty through impeccable service delivery.

Travellers can now book every itinerary of their trip through the internet, but there are various issues which need to be addressed when booking online:

a) a. Privacy Concerns

b) b. Easy Accessibility

c) c. Cost comparison of the services

d) d. Redressal of grievances

e) e. Freedom to choose the services without any hassles

f) f. Certain services should be made available on all seven days of the week and twenty-four hours a day

\section{Review of Literature}

Review of the literature indicates that in the field of e-commerce there are many functional service qualities which are valued by customers during online purchase such as fast connectivity, security issues and user-friendly network (Dhar and Wertenbroch, 2000).

Perceived value is built during the purchasing process whereas satisfaction is evaluated post-purchase as revealed through various 
studies. Perceived value is related to the trade-off between benefits and sacrifices (Changet al. 2009)

Prior studies indicate that service quality is linked to customer satisfaction (Mouakket and Al-hawari, 2011) and loyalty intention (Sadehet al., 2011).Very few studies have investigated the impact of service quality on perceived value and the ones who have conducted research do not differentiate between the functional and hedonic dimensions of service quality which leaves scope for further research. Ravald and Gronroos (1996) touched upon the value concept as the ability to provide superior quality to the customers and concluded that customer satisfaction was more than just a perception of the quality received.

Consumers tend to buy familiar and well-known products as they feel more confident that they are actually buying reliable products from reputed brands (Chi et al., 2009). A positive image through word of mouth is essential for boosting brand awareness (Kim et al., 2004). Huang (2008) found that loyalty to an online travel agency resulted in an increased intention to purchase from that agency.

Loyalty refers to the psychological commitment that a customer makes in the act of purchasing (Nam et al., 2011) This commitment may eventually result in the final intention to purchase or recommend. Brand loyalty has a strong impact on purchasing intention (Hawes and Lumpkin, 1984).

Lang (2000) indicates that many travel consumers surf the web but are reluctant to book online, preferring more conventional and traditional travel networks. The Internet serves as a mode to extract information while very few users who surf the internet book online. This makes the literature review indecisive on how to represent the online purchasing behaviour of consumers. Purchasing intention does not in any way represent a shortcoming as there is significant indication of the existence of a causal link between intention and buying behaviour (Venkatesh and Davis, 2000) 


\subsection{E-Commerce}

E-commerce is defined as buying and selling of goods and services by consumers and businesses on an online mode. The internet and e-commerce provide an opportunity to the tourist to collect information and eventually transact online. E-commerce helps the travellers to purchase services as per their requirements and it is also less time-consuming. But the travellers find it difficult to develop trust online and they are apprehensive about sharing their financial credentials online as it may result in online fraud and theft. Prospective travellers are always on the lookout for quality service while buying the services online. They want the services to be qualitative and reliable. Online travel aggregators and portals should be competitive and creative thus providing an array of travel-related services so that they can compete with traditional travel agencies.

\subsection{Online Tourist Behaviour}

Hotels are of paramount importance in the tourism industry. Tourists have varying tastes and long for a peaceful stay in a hotel. Hotels are striving for efficient customer service to the travellers. The category of tourists can be those visiting for leisure purposes and business-related purposes. E-CRM is a technological tool used for electronic distribution of information and marketing the products and services of hotels. This medium is used by the hotel corporations to help and support the travellers by engaging them in a strong interactive relationship and selling their products efficiently. The website of the hotel which is the first point of contact should be highly informative. The hotel website also provides the facility to book the hotel room according to their choice, liking and budget online. This can be carried out electronically through the magic and power of the Internet. 


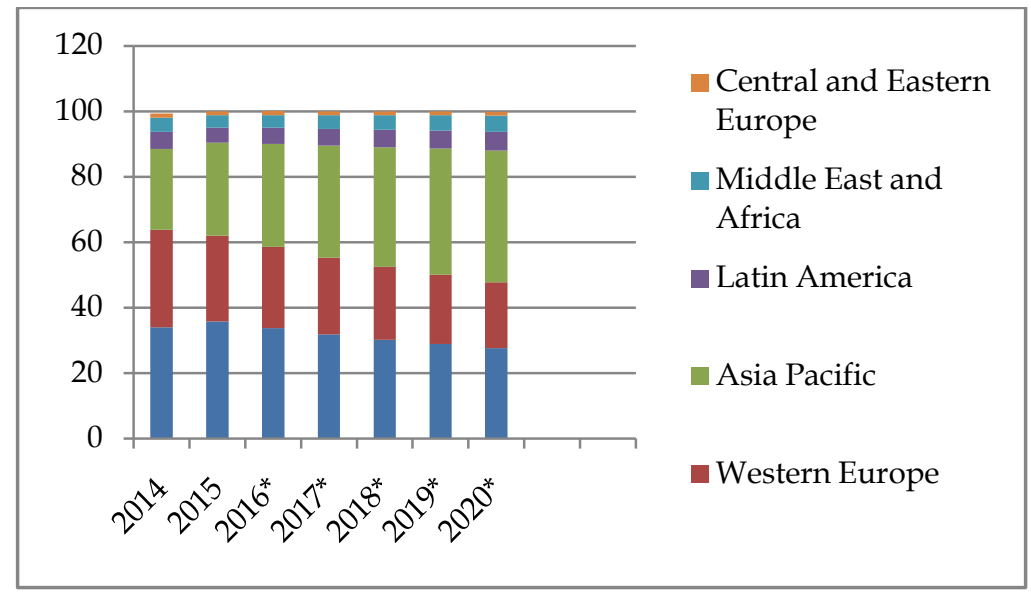

Figure 1: Distribution of digital travel sales worldwide from 2014 to 2020, by region

Source:www.statista.com

Share of global digital travel sales 2014-2020, by region (By Percentage)

Table 3: Distribution of digital travel sales worldwide from 2014 to 2020, by region (By Percentage)

\begin{tabular}{rrrrrrr}
\hline Year & $\begin{array}{c}\text { North } \\
\text { America }\end{array}$ & $\begin{array}{c}\text { Western } \\
\text { Europe }\end{array}$ & $\begin{array}{c}\text { Asia } \\
\text { Pacific }\end{array}$ & $\begin{array}{c}\text { Latin } \\
\text { America }\end{array}$ & $\begin{array}{c}\text { The } \\
\text { Middle } \\
\text { East and } \\
\text { Africa }\end{array}$ & $\begin{array}{c}\text { Central } \\
\text { and } \\
\text { Eastern } \\
\text { Europe }\end{array}$ \\
\hline 2014 & 34 & 29.8 & 24.7 & 5.3 & 4.3 & 1.2 \\
2015 & 35.8 & 26.2 & 28.4 & 4.6 & 3.8 & 1.2 \\
2016 & 33.8 & 24.8 & 31.5 & 4.9 & 3.9 & 1.2 \\
2017 & 31.8 & 23.5 & 34.3 & 5.1 & 4.1 & 1.2 \\
2018 & 30.2 & 22.3 & 36.6 & 5.3 & 4.4 & 1.2 \\
2019 & 28.9 & 21.2 & 38.5 & 5.5 & 4.7 & 1.2 \\
2020 & 27.6 & 20.2 & 40.2 & 5.7 & 5 & 1.2 \\
\hline
\end{tabular}

The airline industry is also not far behind, and the air service providers are aware of the fact that they can cater to the whole of the market because of the varying tastes and preferences of the prospective travellers. The airline companies are striving hard and strategizing so as to reach and understand the mindset of 
prospective travellers. They take the assistance of web technologies to tap into the prospective tourist's pool. Employing enterprise application and ICT have helped the aviation companies to offer genuine and quality services to the travellers and even connect with travellers who use these new technologies. Radio Frequency Identification tags have been employed by airline companies to keep track of the luggage of their valued customers. Airlines employ different techniques such as Frequent Flyer Programs, collecting adequate information about their valued customers and taking regular feedback from them to build a long-term relationship with the customers.

The Internet has revolutionized the tourism industry globally, and successful corporations have adopted the power of technology. It is arguably the most vital and competitive marketing tool for the present and future tourism Industry. Online power dynamics has now taken a giant leap as existing and prospective customers are now sharing more information like never before. They are exercising immense pressure on existing internet content. They are actively involved in writing blogs and have a marked digital presence on the social media. This huge digital transformation has transformed the mindset of the policymakers, and there is a complete transformation in the way travel services are marketed, distributed and eventually sold. Even 'traditional companies are focusing their attention online to increase their reach and tap a wider segment of prospective travellers.

Information is a key and decisive element in planning, booking, and during post-trip and also travel planners and online travel aggregators are developing online marketing strategies to cater to the needs of the existing and prospective travellers since the majority of these populations have an online presence.

\section{Conclusion}

Information and Communication Technology has revolutionized the travel and tourism industry. The benefits accrued through the Internet are multiple as it has cut the barriers between the buyers and the sellers across the service sector domain and there is a marked and a dominant interactivity between both the buyers and 
the sellers. The trends indicate a shift in the online buying behaviour of existing and prospective travellers. This opportunity has been cashed upon by travel service providers and online travel aggregators. They have moved to all the geographic nooks and corners from where they can serve their valued customers round the clock. The Travel and Tourism Industry is no exception by any means. The marketers of tourism products and services are utilising web technologies to their greatest advantage. Besides buying the travel services online, the prospective and existing travellers have also started availing all the other facilities online such as grievance redressal. This technological diffusion in the tourism industry is eventually helping in improving the quality of services and the efficiency of production of a bouquet of services. It is also helping to generate more demand for new innovative services for the burgeoning travel and tourism industry.

\section{References}

Choi, S., \& Kimes, S. E. (2002). Electronic distribution channel's effect on hotel revenue management. Cornell Hotel and Restaurant Administration Quarterly, 43(3), 23-31.

Dabas, S., \& Manaktola, K. (2007). Managing reservations through online distribution channels: An insight into mid-segment hotels in India. International Journal of Contemporary Hospitality Management, 19(5), 388396.

Eggert, A., \& Ulaga, W. (2002). Customer perceived value: A substitute for satisfaction in business markets? Journal of Business $\mathcal{E}$ Industrial Marketing, 17(2-3), 107-118.

Fotis, Buhalis, \& Rossides. (2011). Social media impact on holiday travel planning: The Case of the Russian and the FSU markets. International Journal of Online Marketing,1(4), 1-19.

Gale, B. T. (1994). Managing customer value. New York: Free Press.

Ghosh, S. (1998). Making business sense of the Internet. Harvard Business Review, 76(2), 126-135.

Han, J., \& Han, D. (2001). A framework for analyzing customer value of Internet business. Journal of Information Technology Theory and Application, 3(5), 25-38.

Harris, L., \& Duckworth, K. (2005). The future of the independent travel agent: The need for strategic choice. Strategic Change, 14(4), 209-218. 
Hsu, H. (2006). An empirical study of web site quality, customer value, and customer satisfaction based one-shop. The Business Review, 5(1), 190-193.

Huizingh, E. (2000). The content and design of websites: An empirical study. Information \& Management, 37(3), 123.

Internet World Statistics. (2014). Internet Users in the world-distributions by world regions. Retrieved December 08, 2016, from http://www. internetworldstats.com/stats.html

Joint Hospitality Industry Congress. (2000). Leisure in the new millennium. London: Barclays.

Joo, J. (2007). An empirical study on the relationship between customer value and repurchase intention in Korean Internet shopping malls. The Journal of Computer Information Systems, 48(1), 53-62.

Keeney, R. L. (1992). Value-focused thinking: A path to creative decisionmaking. Cambridge, MA: Harvard University Press.

Keeney, R. L. (1994). Creativity in decision making with value-focused thinking. Sloan Management Review, 35(4), 33-41.

Zeng, B., \& Gerritsen, R. (2014). What do we know about social media in tourism? A Review. Tourism Management Perspectives, 10, 27-36. 